\title{
LAND READJUSTMENT APPLICATION IN COLOMBIA: COUNTERMEASURES TO GENTRIFICATION THROUGH PUI
}

\section{コロンビアにおける区画整理の 適用：PUI を通じた市街地環境 整備への対応}

\section{Carolina BLANCO — $* 1$}

Hidetsugu KOBAYASHI $-* 2$

Keywords:

Colombia, Land readjustment, Slum districts, Gentrification, Community planning, PUI, Dubai International Award 2008

キーワード :

コロンビア, 区画整理, スラム地区, ジェントリフィケーション,

コミュニティプランニング, PUI, ドバイ市国際賞 2008
ブランコ・カロリーナ— $* 1 \quad$ 小林英嗣 — $* 2$

Historically, the term gentry comes from the Old French genterie ${ }^{1)}$ referring to land owners of a certain social status. Urban gentrification however, is a contemporary term associated with a process of change in social network composition, demographics, land use, build structure and real estate price. While for some scholars gentrification may be linked positively with renewal programs, this paper discusses the social consequences of displacement and the use of Land Readjustment and other strategies by the local government of Medellin, Colombia through Integral Urban Projects (PUI). Partial results of the Impact Assessment Study IAS 2008, designed by the authors and applied through direct interviews with more than 150 families involved in the pilot project are included.

\section{Introduction}

According to the United Nations Population Fund (UNFPA), for the first time in history, since 2008 more than half of the world's population lives in urban areas. As noted by Haddad et al. (1999) and cited by Dufour ${ }^{2)}$, even though the overall rate of urbanization at the end of the 20th century remained higher in Latin America (75\%) than it was in either Africa (38\%) or Asia (38\%), for the current century, the urban population of Africa and Asia will double in less than a generation, creating an unprecedented challenge to counteract increasing poverty and environmental degradation through the promotion of development and sustainable design. The UN World Urbanization Prospect 2006 pointed out that an estimated 37 per cent of the urban population in less developed regions was living in slums, while in the least developed countries, almost three quarters of the urban population were slum dwellers ${ }^{8}$. In the case of Latin America, the pace of rural-to-urban migration accelerated in the 20th century in a period of about fifty years, when it shifted from predominantly rural, to predominantly urban (Dufour and Piperata 2004). This affected the capacity of local government to cope with housing demands and urban services, resulting in the formation of several urban slums usually located at the peripheral areas of the largest cities of the region, sadly known as "misery belts".

This paper presents the results obtained from the Impact Assessment Study (IAS) 2008 applied within a former slum neighborhood under the pilot project Housing Consolidation and Environmental Recovery Program (HCERP) at the Juan Bobo Stream Basin Areas.

Headed by the local Government of Medellin Colombia, through the Urban Development Company EDU, the project was developed inside one of the most vulnerable districts in the country, including activities such as land regularization, domiciliary public services supply, renovation and construction of new dwellings, land readjustment and public space provision, while avoiding gentrification effects. In November 2008, the pilot project was selected as one of the ten best practices in the world to improve living environment, and was awarded the biannual Dubai International Prize 2008 [1], administered by the Dubai Municipality United Arab Emirates and the United Nations Center for Human Settlements (UNCHS) ${ }^{[1]}$.

\section{Background and Literature Review}

The HCERP included various strategies for urban recovery to support the quality of life of the residents inside the micro-territory formerly known as Juan Bobo Neighborhood. This paper introduces one of the various techniques employed: namely land readjustment, argues about its potential application in the slum districts' upgrading programs, without encouraging gentrification

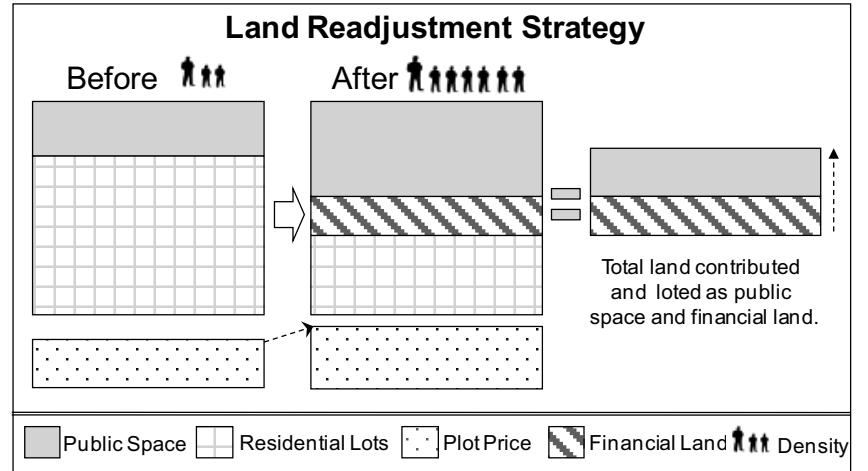

Fig. 1 Land Readjustment and the generation of new public space. Adapted from Tanaka H. 2004 [2]
Ph.D. Candidate, Laboratory of Urban and Regional Design, Graduate School of Engineering, Hokkaido Univ., M. Eng.

2 Prof., Laboratory of Urban and Regional Design, Graduate School of Engineering, Hokkaido Univ., Ph.D.
北海道大学大学院工学研究科都市地域デザイン学研究室 博士課程
$($ 厂 $060-8628$ 札幌市北区北 13 条西 8 丁目- A251) (テ 060-8628 札幌市北区北 13 条西 8 丁目-A251)

北海道大学大学院工学研究科都市地域デザイン学研究室 教授・工博 


\subsection{Land Readjustment in Latin America}

Land Readjustment - LR or Kukakuseiri, has been applied worldwide for more than a century and has been called the "mother of city planning" in Japan ${ }^{3)}$. It is a development strategy with a redefinition of the limits of land units and land uses, which involves the original land owners ${ }^{9)}$, while creating new public space and providing the so-called financial land, in order to generate economic resources to be reinvested within the project (Fig.1).

The need to develop new strategies of urbanization able to cope with past migration tendencies from rural areas to the city, against sprawl and slum district's expansion in Latin America, has been addressed for decades in academic and policy making scenarios. LR has been discussed as an option to redefine the core environmental and urban planning policy (ordering of the territory). Specifically, LR projects are expected to contribute by clarifying land tenancy titles; evaluate the use and occupation of the land as a way to anticipate and control forthcoming developments derived from ongoing massive transportation projects (promotion of Transport Oriented Development or TODs); encourage the redevelopment at the city centers and selected areas and to optimize the use of the land, given that eventual expansion into metropolitan areas puts pressure upon the use of the best agricultural land

\subsection{Approaches to gentrification}

The term "gentrification" has dual perspectives and hence is usually a concept of divided opinions (See Glass 1964, Marcuse 1985, Smith 1996, and Atkinson 2001 as cited in Slater 2006). It may be associated in a positive or negative way, depending on the society that experiences the social and economic change. As Slater (2006) suggests, for some people captured by the picturesque idea of gentrification "the perception is no longer about rent increases, landlord harassment and working-class displacement, but rather street level spectacles, trend bars and cafes, i-Pods, social diversity and funky clothes outlets"7). However, for those sent away from their original neighborhoods, the perception is not so amusing. Usual definitions emphasize the economic perspective that foster the neighborhood's changes, without detailing the circumstances and the efforts of the original settlers to change their environment. Taking for instance Random House's Webster's College Dictionary (1999) definition, the word gentrification is "the upgrading of run-down urban neighborhoods by affluent people who buy and renovate the properties, thereby displacing the resident poor"6), while the
Longman Dictionary of Contemporary English (2003) defines gentrification as: "a gradual process in which an area in bad condition where poor people live, is changed by people with more money, coming to live there and improving it" ${ }^{4)}$

After gentrification starts, local settlers are incentivized to take roots elsewhere. However, as described by Marcuse (1985) "displacement from home and neighborhood can be a shattering experience. At worst it leads to homelessness, at best it impairs a sense of community. Public policy should, by general agreement, minimize displacement" 5). Instead of gradually disrupting their social network, as shown in Fig. 2ii, a coexistent alternative between different socio-economic groups that could encourage social integration and tolerance is proposed in Fig. 2iii, suggesting that upgrading programs should foster basic neighborhood enhancing elements (a. sanitation; b. quality of public spaces and c. income opportunities). Through LR and urban integral approaches to be described in brief, new social groups could be integrated, without displacing the original settlers.

\section{The Heartfelt Houses Pilot Project and the PUI}

The city of Medellin, with a population of 2,223,078 (National Census 2005), is subdivided into 16 administrative communes. Communes 1 and 2 with the lowest human development index levels of the city were selected by the local government of Medellin to introduce the Urban Integral Programs (known as the PUI due to its acronym in Spanish), carried out by the EDU. Communes 1 and 2 are located at the northeastern area of Medellin in a territory which was characterized by an intricate topography, lack of good transportation systems, unemployment, poverty and high crime rates throughout several informal districts where illegal settlements have formed since the latter half of the last century, plus some neighborhoods that acquired legal status after long regularization processes.

\subsection{Initial Situation}

The northeastern communes were stigmatized in the past as being one of the most dangerous, poorest and isolated areas on the periphery of Medellin. Environmental conditions and safety problems caused by landslides in the rainy season, contamination of the main streams, continuous development of overpopulated squats, and social consequences of local violence became an unbearable yet continuous situation. The neighborhood selected as the pilot project is named "Juan Bobo" which translated to English is "Silly John",

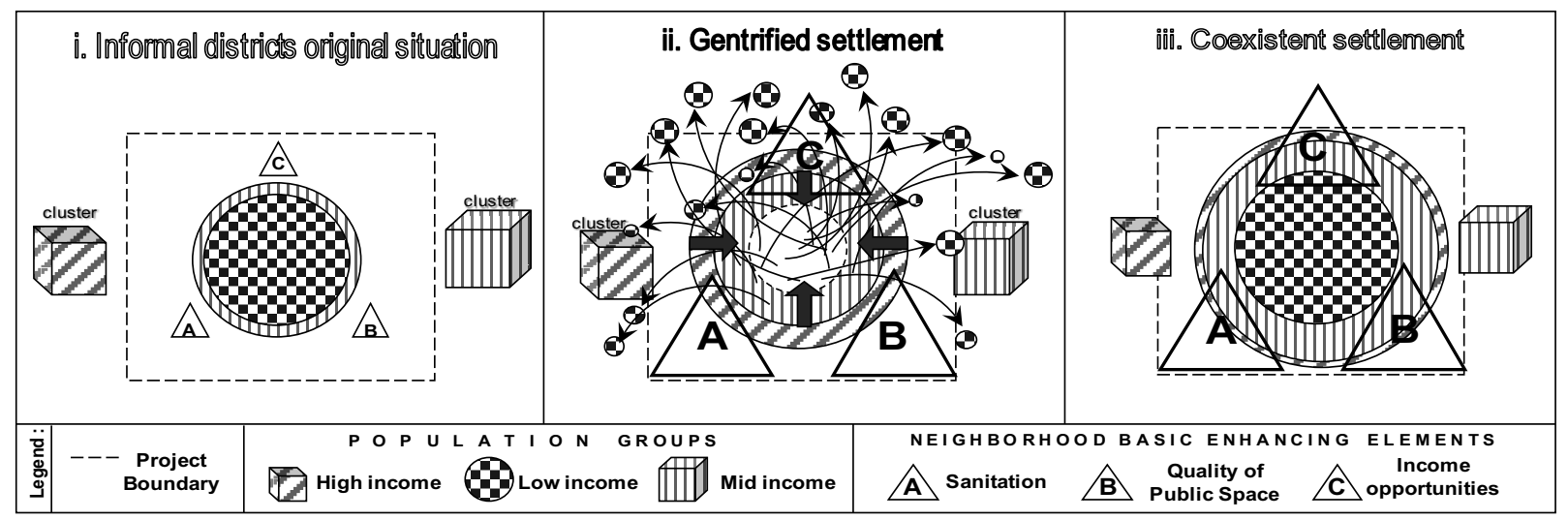

Fig. 2 Theoretical Diagrams of informal districts common cases: i). Original situation characterized by low or no factors of attraction , ii). Gentrified settlement incentivize displacement and exchange of population, iii). Coexistent settlement voluntarily protects the weakest group facilitating it to remain in the area, while promoting an inclusive model open to all population groups. 
following the name of the main stream that crosses the site from east to west. The Habitat Consolidation and Environmental Recovery Program (HCERP) of the Juan Bobo Stream Basin Areas at Commune 2 started in 2004 and its first stage was completed in 2008. The HCERP started as a pilot project that introduced land readjustment practices adapted as onsite resettlements, housing consolidation, public space generation and environmental protection for the Juan Bobo stream. According to EDU, $77 \%$ of the total households reported an income approximate to or below the minimum monthly salary in Colombia before the beginning of HCERP. The lack of public space was particularly critical at the stream bed, being estimated by EDU in $0.5 \mathrm{~m}^{2}$ per resident, making access and circulation difficult and uncomfortable. Before the project started, $80 \%$ of the houses had structural and functional shortages, $35 \%$ were located in the riverbed restricted areas, and $94 \%$ lacked legal tenure. $100 \%$ of the sewage was informal, being discharged directly into the stream, through self-installed pipes.

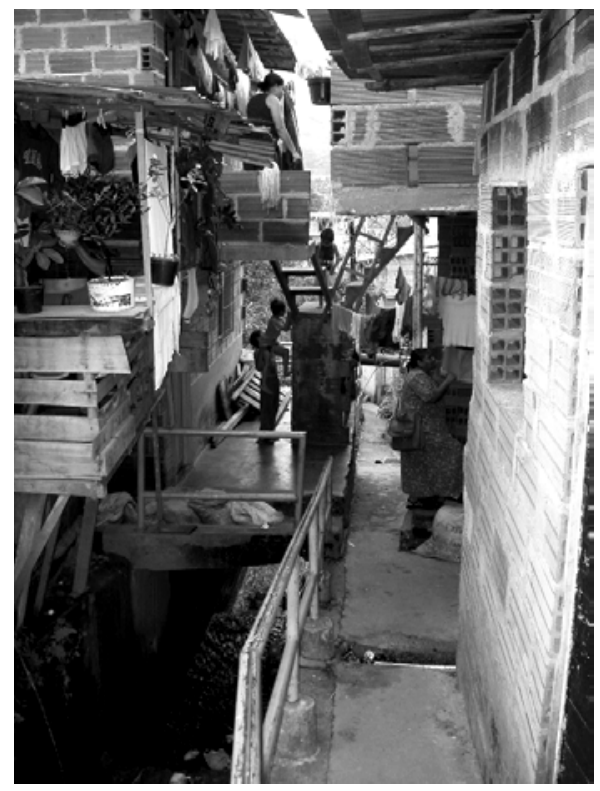

Fig. 3 Before the HCERP, shanty houses cobbled together with wood, bricks and metal sheets crowding towards the asphyxiated Juan Bobo stream. Courtesy: EDU
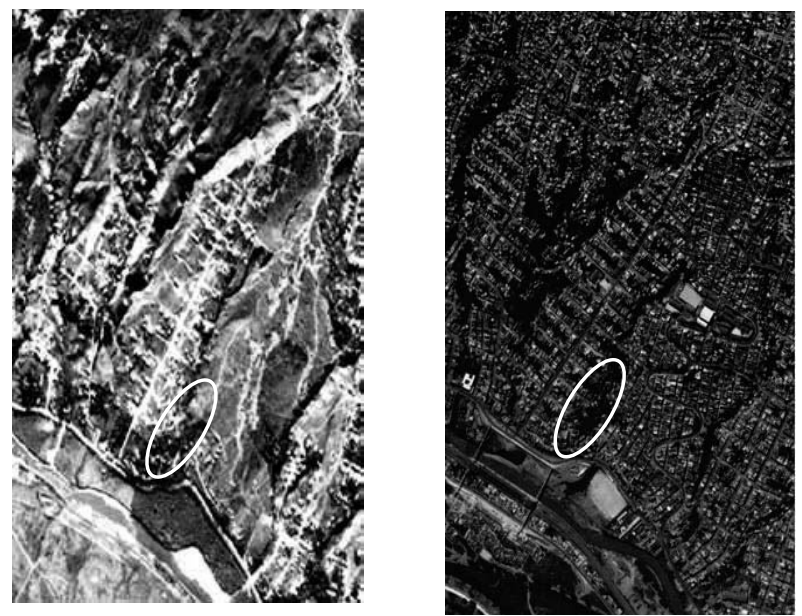

Fig. 4 and 5: Contrasting aerial photographs in the early and late 20th century over Communes 1 and 2. In both pictures a central axis is visible (Str-107) close to the project's area which has been marked with an oval. The Metrocable system follows the Str. 107 axis. Courtesy of Pontificia Bolivariana University LAUR.
Table 1 Pilot Project HCERP at Juan Bobo stream in numbers Source: EDU Urban license chart

\begin{tabular}{|c|c|l|l|}
\hline Item & Unit & Previous value & Current value \\
\hline gross area & $\mathrm{m}^{2}$ & $17,775.66$ & $17,775.66$ \\
\hline net area & $\mathrm{m}^{2}$ & $17,414.96$ & $17,414.96$ \\
\hline occupied area & $\mathrm{m}^{2}$ & $9,123.86$ & $5,366.35$ \\
\hline public space & $\mathrm{m}^{2}$ & $5,120.32$ & $6,772.61$ \\
\hline density & house/ha & 102 & 118 \\
\hline housing area 1F & $\mathrm{m}^{2}$ & $6,494.15$ & $5,727.05$ \\
\hline occupation index & $\%$ & 37 & 31 \\
\hline constructions & dwellings & 182 & 210 \\
\hline
\end{tabular}

\subsection{Key Programs and Results}

The PUI included social programs with the community, environmental workshops, a peace process with gang groups that used to transgress within the area and which agreed to dissolve and stop confrontation, relocation and reinforcement of the local police structure and solidarity-oriented financial measures which allowed huge investments into this part of the city. Worthy of noting is the transformation of public transport options within the area, through the introduction for the first time in urban history of a massive transportation system known as "Metrocable" (aerial mono-cable gondolas with a capacity for 10 people each). It is directly connected without additional fee to the city's massive transportation system: "Metro". The "Metrocable" runs through a 2072 meter course along three stations and has an installed capacity to transport 3000 people per hour.

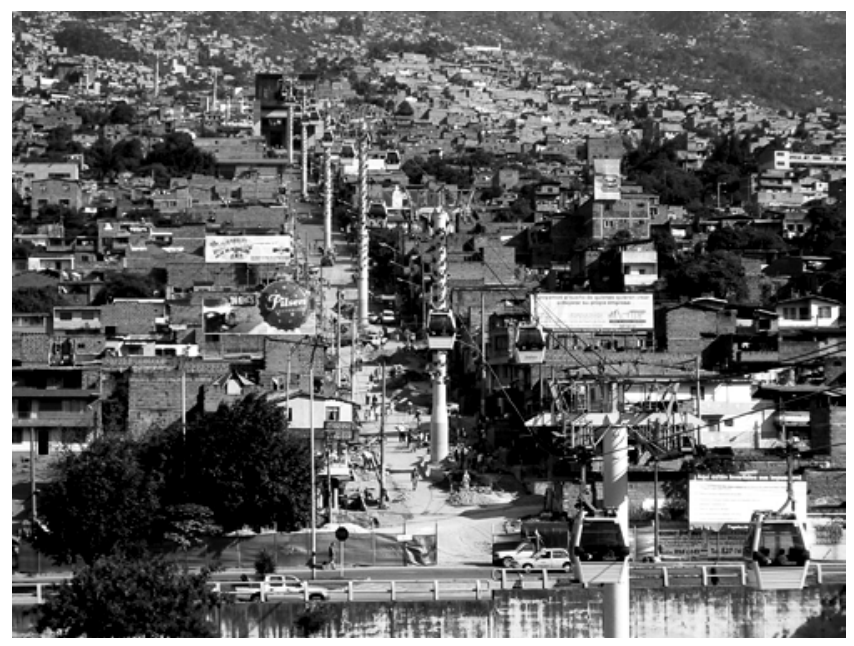

Fig. 6: "Metrocable" massive transportation system was inaugurated in 2004. Gondolas crossing by air the northeastern Communes of Medellin city. C Blanco 2005

The following three components established by the PUI strategy became the core elements of the general program:

a. Institutional component: aimed at the coordination of several groups and multidisciplinary parties, including the public sector, private enterprises, non-government organizations, universities and the civil society.

b. Community participation: developed once the institutional component was started, it became the central axis of action. It included intense fieldwork to gain the trust of the community and to get direct information about the level of need. This close relationship included an employment program to hire some residents as part of the labor force for the construction works, providing technical training and income opportunities

c. Physical component (known as the three-dimensional result), it translated 
the ideas into subprograms focusing on four fronts: housing, public facilities, environment and public space $\&$ transport (Table 2).

Table 2 PUI Main components Source:EDU

\begin{tabular}{|c|c|c|c|}
\hline \multicolumn{4}{|c|}{ PUI: Integral Urban Project } \\
\hline \multirow{7}{*}{ 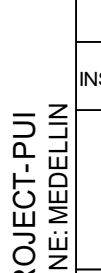 } & \multicolumn{2}{|c|}{ COMPONENTS } & ACTIONS \\
\hline & \multirow{2}{*}{\multicolumn{2}{|c|}{ INSTITUTIONAL COORDINATION }} & INTERINSTITUTIONAL COORDINATION \\
\hline & & & INTERSECTORIAL COORDINATION \\
\hline & \multirow{4}{*}{ SOCIAL } & \multirow{4}{*}{$\begin{array}{c}\text { COMMUNITY } \\
\text { PARTICIPATION } \\
\text { AND } \\
\text { COMMUNICATION }\end{array}$} & IDENTIFICATION \\
\hline & & & VALIDATION \\
\hline & & & PARTICIPATION \\
\hline & & & EDUCATION \\
\hline \multirow{9}{*}{ 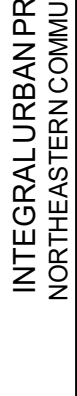 } & \multirow{9}{*}{ PHYSICAL } & \multirow{3}{*}{$\begin{array}{l}\text { PUBLIC SPACE } \\
\text { \& TRANSPORT }\end{array}$} & CONSTRUCTION OF NEW PUBLIC SPACES \\
\hline & & & $\begin{array}{c}\text { IMPROVEMENT OF EXISTING } \\
\text { PUBLIC SPACE }\end{array}$ \\
\hline & & & $\begin{array}{l}\text { ORDERING OF THE PUBLIC } \\
\text { TRANSPORT SYSTEMS }\end{array}$ \\
\hline & & \multirow{3}{*}{ HOUSING } & NEWHOUSING CONSTRUCTION \\
\hline & & & HOUSING IMPROVEMENT \\
\hline & & & HOUSING LEGAL TENANCY \\
\hline & & \multirow{2}{*}{$\begin{array}{l}\text { PUBLIC } \\
\text { FACILITIES }\end{array}$} & IMPROVEMENT OF COMMON FACILITIES \\
\hline & & & CONSTRUCTION OF NEW FACILITIES \\
\hline & & ENVIRONMENT & ENVIRONMENTAL RECOVERY \\
\hline
\end{tabular}

Tangible works are listed in Table 3. However, key achievements include pedagogical activities, cleaning and ecological activity trips, communitarian agreements, and the authoring of a manual on codes of behavior (Manual de Convivencia) written with direct participation of the residents.

Table 3 Results Source:EDU

\begin{tabular}{|c|c|c|}
\hline Item & Unit & value \\
\hline new constructions & Apartment towers & 8 \\
\hline Improved housing & dwellings & 116 \\
\hline $\begin{array}{c}\text { Housing available for newcoming } \\
\text { households }\end{array}$ & dwellings & 24 \\
\hline New housing for existing households & dwellings & 120 \\
\hline walking paths & $\mathrm{m}$ & 3900 \\
\hline adequate public space & $\mathrm{m}^{2}$ & 5600 \\
\hline protected areas for the environment & $\mathrm{m}^{2}$ & 1500 \\
\hline Legal processed dwellings & real estate titles & 236 \\
\hline
\end{tabular}

\section{Impact Assessment Study IAS-2008: purpose and methodology}

Between February and May of 2008, an Impact Assessment Study designed by the authors and conducted with the support of the EDU and the Pontificia Bolivariana University's Faculty of Architecture, was developed using questionnaire-based interviews (Table 4). Each interview was divided into 15 sections collecting qualitative and quantitative data and taking an average of 72 minutes to be completed. The questions covered a range of topics including the resident's perception of the condition of public and private spaces, environmental relations, and behavioral attitudes among others.

A household representative was asked to provide the information from all the living members of the unit, and s/he participated with drawings, geographical location skill exercises, comparisons, and life testimonies regarding their quality of life. Besides all the questionnaires, photographical, video and audio records make part of the collected data.

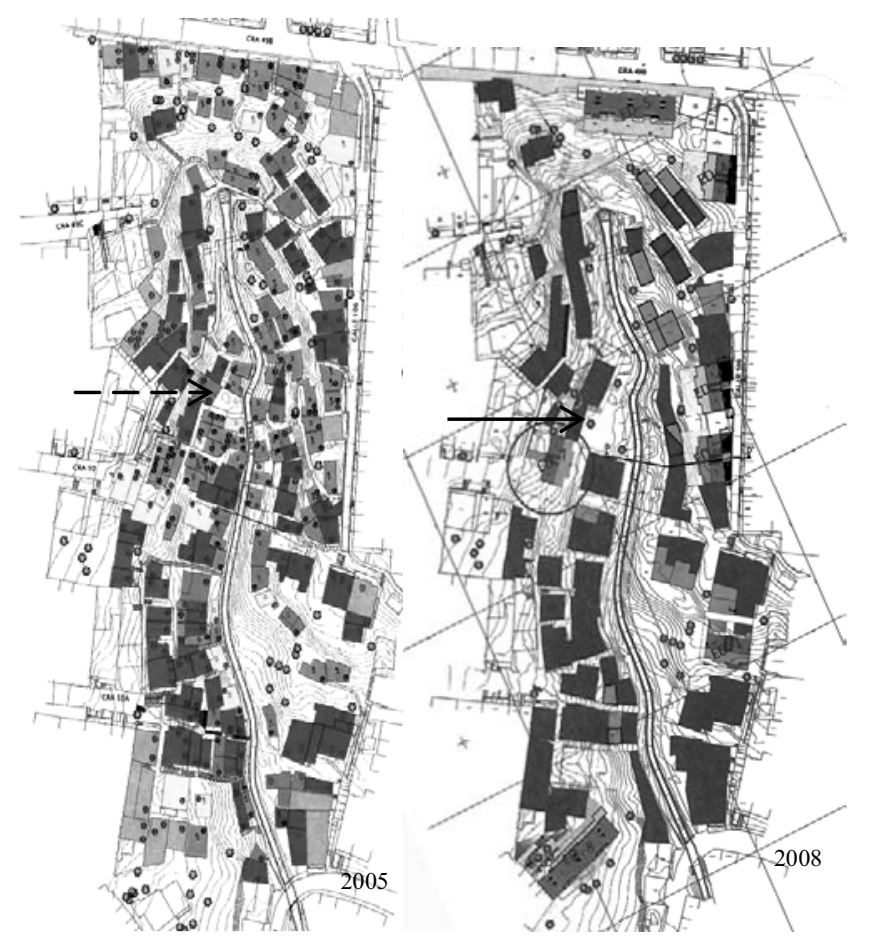

Fig. 7 (left) Dwellings disperse and crowd around the stream bed as in 2005 and Fig. 8 (right) Land readjusted project completed. Arrows point the Wishes' square Source: EDU

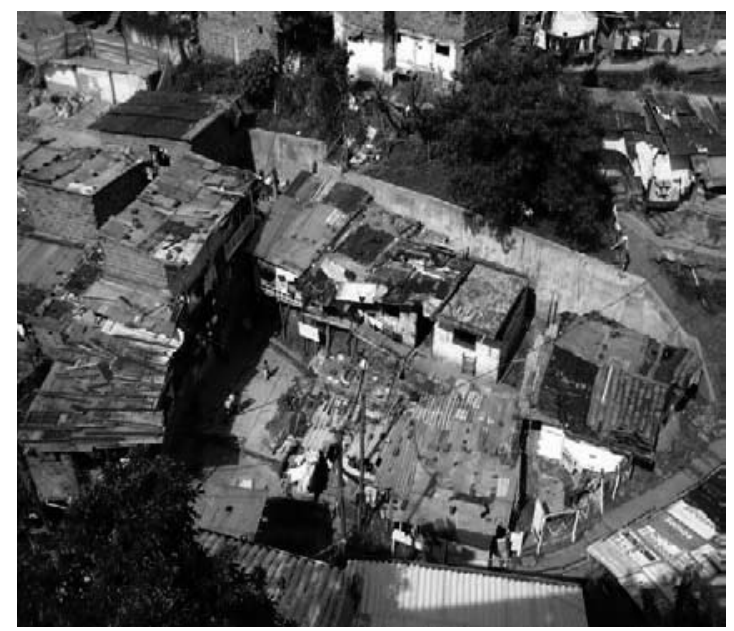

Fig. 9 Before HCERP: Single community open space at Juan Bobo neighborhood. Courtesy: EDU 2005

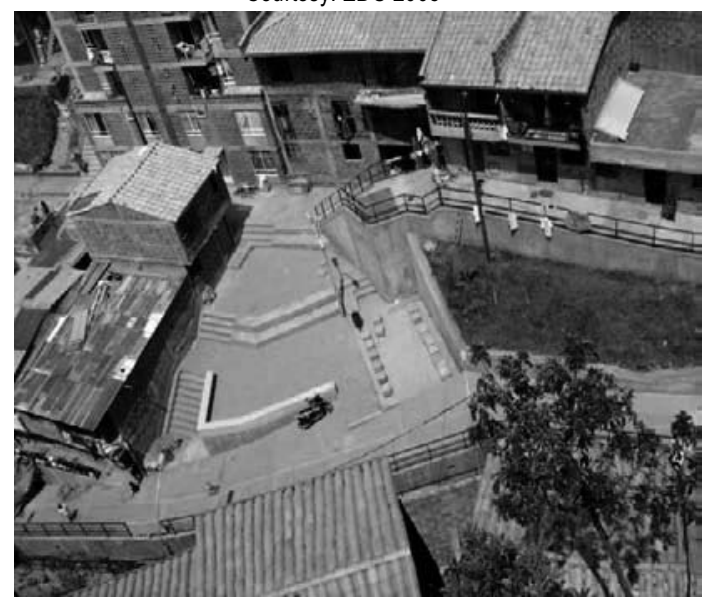

Fig. 10 After the HCERP the same open space named as the Plaza de los Deseos (Wishes' Square). Courtesy: EDU 2008 


\subsection{Selected findings from the IAS 2008 in reference to Gentrification}

Given the extension of the IAS, the current paper focuses on information linked directly or indirectly to gentrification vulnerability and land readjustment implications, summarized in the following 3 sections:

A. Household Profile and Composition: From the 122 valid households interviews, 163 nuclear families ${ }^{[3]}$ were identified suggesting that at least $25 \%$ of the households presented some kind of extended family structure. The study also showed a high rate of single-mother units (Fig. 12). The reasons for these cases, being relatively common, were not measured technically by the questionnaire.

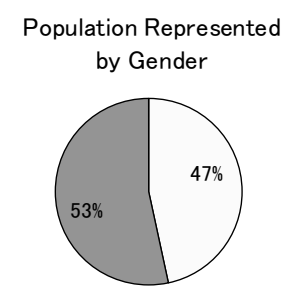

$\square$ Men $\square$ Women
Singlemother rate

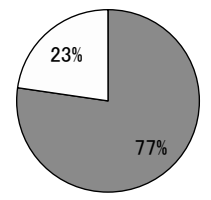

QRest of households $\square$ Single mother household
Fig. 11 Population represented by gender and Fig. 12 Single motherhood

Figure 13 compares the population distribution according to the IAS information of the pilot project, with the current Colombian average population distribution dividing both series into 8 groups of ascending ages

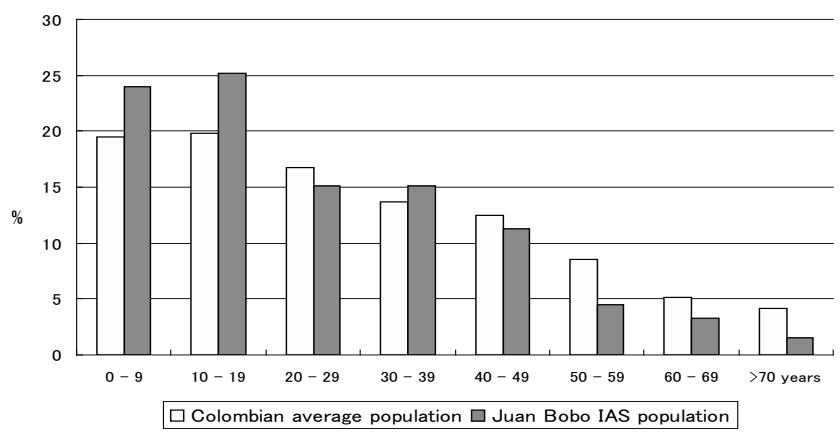

Fig. 13 Parallel between Colombian average population and Juan Bobo stream population by age groups.

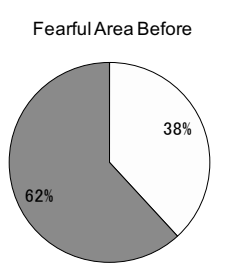

$\square_{\text {safe }} \square_{\text {fear }}$

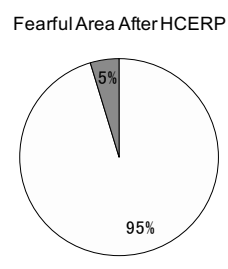

$\square$ safe $\square_{\text {fear }}$
Fig. 14 and 15 Neighborhood's area associated with fear before and after the project.

B. Sense of Security in Open Areas: To grasp perceptional levels in this aspect, one of the questions required the respondents to approximate the total area of the neighborhood of which they were fearful before (62\%) and after the HCERP was developed (5\%). Results show a dramatically changed perception after the project was completed. Besides delinquency, some respondents reported to live afraid of losing their homes due to natural disasters or evicted by authorities, given the lack of land tenancy titles.

C. Environmental Perceptions regarding the "Juan Bobo" Stream: All respondents were asked to mark yes or no if a certain statement was valid for their household's attitude toward the "Juan Bobo" Stream. A selection of six questions taken from section 19 of the Educational Visits questionnaire applied in 2006 by the Corporation Prevenir Riesgos y Desastres ("Prevent Risks and Disasters Corporation") were asked again through the IAS 2008, in order to compare the attitudes before and after the project was implemented (Fig. 16i to 16vi).
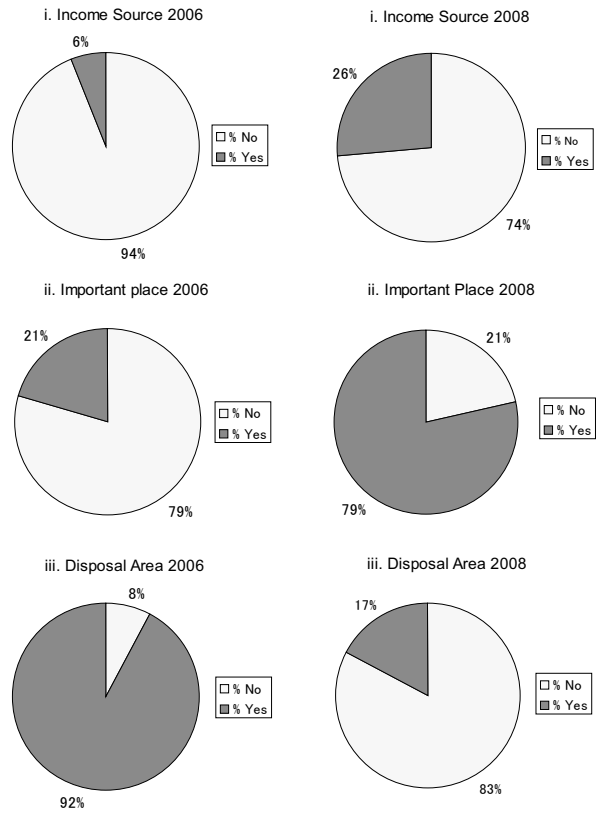

iv. Source of Flooding Risk 2006
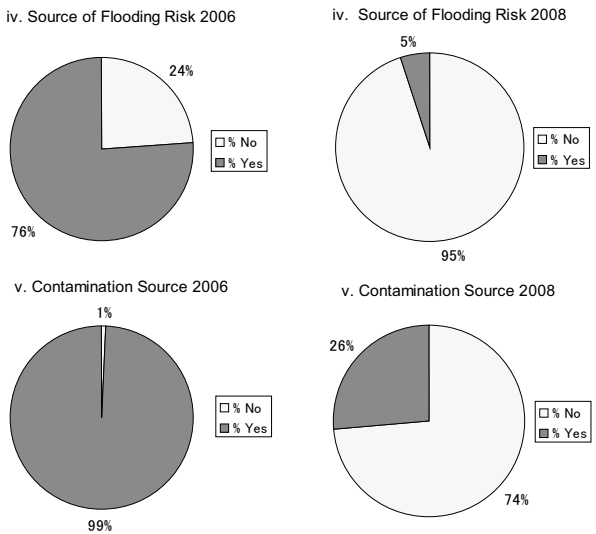

v. Contamination Source 2008
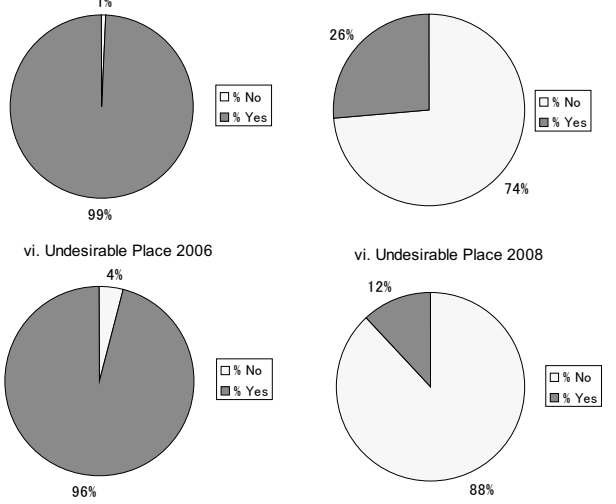

Fig $16 i$ to 16 vi. Behavior and perceptions toward the "Juan Bobo" stream.

\section{DISCUSSION}

This paper first introduced LR as a development strategy to redefine the limits and the uses of the land while actively involving the original owners in the process. It also highlighted the potential to generate new public space and the so-called financial land. The Colombian version of LR applied at the 
HCERP of Juan Bobo stream basin area, included a flexible approach if compared with the Japanese LR standards in terms of valuation. This occurred given the extreme shortages found in some dwellings, that following strict numerical parameters would have not have a sufficient index value to be considered in the project. In fact, many of the households, especially the poorest ones, received more than what they mathematically could have afforded. This was a deliberate action of the project executors to foster an inclusive urbanization pattern.

In the cases of slum districts, the paper suggested that the risk of promoting gentrification is high, given that upgrading the living conditions without providing any kind of complementary support (technical, economical, or social empowerment) could turn residents in weak groups easily convinced and displaced by outsiders. Economical shortage, lack of education and an absent sense of belonging to the area were identified as main factors for becoming gentrified. The following actions were considered decisive to avoid gentrification:

1. A list of the inhabitants was prepared, making a compromise with the members to keep it fixed. The appraisal of their dwellings' constructive details allowed the identification and geographical location of the original community, plus the recognition of their specific needs, as a baseline for the social and technical teams.

2. A networking program with the inhabitants was developed, including workshops and activities sponsored by the local government. The housing communitarian group, the emergency committee, environmental groups and the semillero infantil ("child's seedbed program") which focused on children's education, were created.

3. A national, regional and local subsidy was incorporated as part of the project, for every household to acquire a new dwelling or improve their current one, if and only if the household agreed to live in the same unit for at least 5 years, prior to any kind of real estate purchase and after confirmation that no previous national housing subsidy had been granted.

\section{CONCLUSIONS}

(1) Protection from displacement in cities requires complex policies that should be guided by local institutions socially committed to the urban poor, and as much as possible in association with the private sector and the community. The political framework of the PUI in contrast with previous practices enabled the investment of public resources into areas of the city with urban substandards and low levels of enhancing elements. Before improving basic needs, it was imperative to carry out extensive social and community networking tasks.

(2) The IAS's population below the age of 39 (Figure 13) is higher than the national average population, with the exception of the age group between 20 and 29, where the population is lower ${ }^{[4]}$. When compared with the Colombian average, higher fertility rates, higher infant population and a high level of single mothers $(23 \%)$ were found in the family units studied. Recognizing these differences is fundamental before any kind of program or housing solution can be proposed. Past the age of 39 , the IAS population is consistently lower than the national average population. It is important to note that the segment over 70 years old is less than half of the national average, suggesting possible low life expectancy levels.

(3) The large scale of physical intervention and environmental recovery of the HCERP at the Juan Bobo stream area influenced considerable changes in the perception and use of private and public spaces, encouraging a sense of belonging that was previously absent. Additionally, control measures like the communitarian pacts or the agreement to 5 year tenancy served to prevent gentrification effects. Although the original social network has been preserved, further analysis should be carried out after the $5^{\text {th }}$ year to confirm this claim.

(4) The space shortage and urban disconnections (due to the one-by-one self-construction practice and the original invasion process which is usual in slum areas) was challenged through a Colombian-adapted version of LR as an alternative to clear up and organize the residential environment. The achievements of LR in terms of public space generation (3.17 $\mathrm{m}^{2}$ per resident) and the improvement of living conditions for vulnerable segments of the population suggest its applicability in slum areas while avoiding gentrification.

\section{Acknowledgements}

The authors would like to express their gratitude to the Medellin local government professionals, particularly those of the Taller de Vivienda from the EDU, and the Municipal Planning Department. Also, many thanks to the Japanese Monbukagakusho for the financial support, the Faculty of Architecture of Pontificia Bolivariana University for their collaboration during the IAS 2008 and ultimately to the families of the Juan Bobo neighborhood, renamed as Nuevo Sol de Oriente (New Eastern Sun) for openly sharing their impressions, hopes and concerns with the authors.

\section{References}

1) Dictionary. The American Heritage Dictionary of the English Language, Fourth Edition, Houghton Mifflin Company, 2007

2) Dufour, D.L. and Piperata, B.A.: Rural-to-Urban Migration in Latin America: An Update and Thoughts on the Model, American Journal of Human Biology 16, pp.395-404, 2004

3) Journal of City Planning Institute of Japan. Special Issue: "Power of the Mother of City Planning - 50th Anniversary of Land Readjustment Law Establishment" 53, No. 5 pp. 4,2004

4) Longman Dictionary of Contemporary English. Pearson Education Limited, 2003 pp. 672

5) Marcuse, P: Gentrification, Abandonment, and Displacement, Journal of Urban and Contemporary Law 28,107, pp.195-240, 1985

6) Random House Webster's College Dictionary. 2d. edition. Random House, New York, 1999. pp. 546

7) Slater, T.: The Eviction of Critical Perspectives from Gentrification Research, International Journal of Urban and Regional Research 30, 4. pp.1-23, 2006

8) United Nations: World Urbanization Prospect. The 2006 revision. Department for Economic and Social Information and Policy Analysis

9) Blanco, C: The Influence of Land Readjustment in Japanese Urban Policies and its Possibilities of Application in Colombia, Hokkaido University, 2005.

\section{Notes:}

[1] Available at www.dubaiaward.ae - accessed January 13th, 2009

[2] Prepared after a personal interview with Tanaka Hiromi, 2004.

[3] Understood as a couple with their dependent children

[4] Although not verified statistically yet, some respondents adduced the gap with the national average from this age group, to the violence experimented in the past among youth, although it may be tested in future studies.

[5] Partial content of this paper was presented in 2008 at the $7^{\text {th }}$ International Symposium on Architectural Interchanges in Asia, Urban Renewal and Architecture Creation, in Beijing, China and at Space Interaction Discourse International Conference in Aalborg, Denmark.

[2009 年 2 月 20 日原稿受理 2009 年 4 月 16 日採用決定 $]$ 